\title{
Changes in the abundance and spatial distribution of the Atlantic chub mackerel (Scomber colias) in the pelagic ecosystem and fisheries off Portugal
}

\author{
MARIA MANUEL MARTINS ${ }^{1 *}$, DANKERT SKAGEN ${ }^{2}$, VÍTOR MARQUES ${ }^{1}$, \\ JUAN ZWOLINSKI ${ }^{3}$ and ALEXANDRA SILVA ${ }^{1 *}$ \\ ${ }^{1}$ Instituto Português do Mar e Atmosfera- Algés Av. Brasília, 1449-006 Lisboa, Portugal. E-mail: mmmartins@ipma.pt \\ ${ }^{2}$ Independent consultant, Fjellveien 96, N-5019 Bergen, Norway. \\ ${ }^{3}$ Institute of Marine Sciences, University of California, Santa Cruz, Earth and Marine Sciences Building, Rm A317, \\ Santa Cruz, CA 95064, USA \\ *These authors contributed equally to this work
}

\begin{abstract}
SUMMARY: This study describes changes in abundance and spatial distribution of Atlantic chub mackerel in the Portuguese waters and the Spanish waters of the Gulf of Cadiz using data from acoustic surveys from 1995 to 2010 and data from the fishery since 1958. The distribution and dynamics of chub mackerel and sardine (Sardina pilchardus) are compared and species interactions are discussed. From 2007 to 2009, chub mackerel biomass, as measured acoustically, ranged between 69000 and $238000 \mathrm{t}$ concentrated off the western coast $(\sim 50 \%)$ and in the Gulf of Cadiz $(\sim 30 \%)$. Portuguese landings have varied with periods of high landings around 1970 and in recent years. Since 1986 landings have been between 4000 and $23000 \mathrm{t}$. Both survey catches and commercial landings are taken mainly off the southwestern coast and one- to two-year-old individuals $(20-24 \mathrm{~cm})$ predominate in both. Scarcity of larger individuals may be a consequence of their deeper distribution and avoidance of fishing gear, migration of older individuals or a combination of both. In years with high abundance, the fishery expands to the northwestern areas of the Iberian Peninsula. The expansion appears to be caused by improved recruitment although other factors might have contributed (such as targeting to compensate for low sardine catches and the appearance of new markets). The complementary spatial distribution of chub mackerel and sardine and the inverse correlations between their frequency of occurrence, landings and recruitment indices suggest some interaction between the dynamics of the two species, possibly associated with climatic variation.
\end{abstract}

Keywords: Chub mackerel, sardine, Portugal, pelagic ecosystem, purse seine fishery.

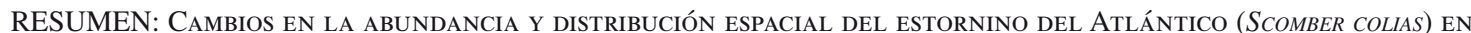
EL ECOSISTEMA PELÁGICO Y PESQUerias De PoRTUgal. - Este estudio describe los cambios en la abundancia y distribución espacial del estornino del Atlántico en las aguas portuguesas y aguas españolas del golfo de Cádiz a partir de datos de las prospecciones acústicas 1995-2010 y datos de la pesquería desde 1958. La distribución y la dinámica del estornino y de la sardina (Sardina pilchardus) se comparan y se analiza la interacción de las especies. Durante 2007-2009, la biomasa del estornino medida acústicamente osciló entre 69 y 238 mil t y se concentró frente a la costa occidental ( 50\%) y en el golfo de Cádiz ( 30\%). Los desembarques portugueses han variado con períodos de altas capturas alrededor de 1970 y en los últimos años. Desde 1986 los desembarques han sido entre 4 y 23 mil t. Ambas capturas de campañas y desembarques comerciales se toman principalmente en la costa sur occidental y individuos de 1-2 años edad $(20$ a $24 \mathrm{~cm})$ predominan en ambos. La escasez de individuos más grandes puede ser una consecuencia de su distribución más profunda y la evitación de las artes de pesca, la migración de los individuos mayores o una combinación de ambos. En los años de mucha abundancia, la pesquería se expande a las áreas occidentales norte de la Península Ibérica. La expansión parece ser causada por un mejor reclutamiento aunque otros factores pueden haber contribuido (pesca dirigida para compensar las capturas bajas de sardina y la aparición de nuevos mercados). La distribución espacial complementaria de caballa y de sardina y la correlación inversa entre la frecuencia de ocurrencia, los desembarques y los índices de reclutamiento sugieren una interacción entre la dinámica de las dos especies, posiblemente asociados a las variaciones climáticas.

Palabras clave: estornino, sardina, Portugal, ecosistema pelágico, pesca de cerco. 


\section{INTRODUCTION}

The Atlantic chub mackerel (Scomber colias Gmelin, 1789) is a pelagic fish distributed in warm and temperate waters of the Atlantic Ocean and in the Mediterranean Sea across the shelf and upper slope. In the eastern Atlantic, chub mackerel occurs from the Bay of Biscay to South Africa, including the Canary, Madeira, Azores and Saint Helena Islands and several seamounts (Castro-Hernández and Santana-Ortega 2000). It may be considered the southern congener of Atlantic mackerel S. scombrus (Villamor et al. 2004). The two species overlap in the Iberian Peninsula, with Atlantic mackerel being predominant to the north and chub mackerel to the south of Lisbon (Martins and Cardador 1996).

S. colias is now considered a separate species from the Indo-Pacific congener S. japonicus, based on mitochondrial and nuclear DNA analyses (Scoles et al. 1998, Collette 1999, Infante et al. 2007). For simplicity, we refer to $S$. colias as chub mackerel and S. japonicus as Pacific chub mackerel. Until recently both species were referred to as $S$. japonicus, and from earlier studies in the Atlantic and Pacific regions, they appear to have a broadly similar life history and population dynamics (Castro-Hernández and Santana-Ortega 2000).

Chub mackerel is a fast growing early maturing species that can attain $50 \mathrm{~cm}$ total length and 13 years of age (Castro-Hernández and Santana-Ortega, 2000). In the Portuguese waters, it grows up to $20 \mathrm{~cm}$ in the first year of life and matures at 1-2 years of age (Martins 2007). Spawning takes place in winter-spring (Martins 1996) at temperatures around $15^{\circ} \mathrm{C}$ to $20^{\circ} \mathrm{C}$ (CastroHernández and Santana-Ortega, 2000). Both juveniles and adults feed mainly on zooplankton although the relative importance of larger organisms such as cephalopods, crustaceans and small pelagic fish increases with the size of individuals (Angelescu 1979, Castro and Hernandéz-García 1995). The ontogenetic change in diet is associated with a tendency for older individuals to be distributed more offshore (Baird 1978).
Migrations across latitude and between coastal and offshore areas, related to seasonal cycles of spawning and feeding, have been described in several areas of the Pacific and Atlantic Oceans (Castro-Hernández and Santana-Ortega 2000). Within European Atlantic waters, spawning grounds and migrations are not well known. The lack of genetic differentiation across the northeast Atlantic and the Mediterranean Sea does not support the existence of homing behaviour to spawning grounds (Zardoya et al. 2004).

Chub mackerel is mostly caught in purse seine and pelagic trawl fisheries which target sardine and/or anchovy (ICES, 2011a, GFCM 2010, FAO 2010a, b). Although it is normally a by-catch, it may provide an alternative income when the availability of the target species is low and its own availability is high. Annual landings in the eastern Atlantic are around 200000 t, with $80 \%$ being caught off northwest Africa (FAO, 2010a). In Portugal, chub mackerel is mainly caught in the purse seine fishery directed towards sardine. Despite its low commercial value, the chub mackerel is second only to sardine in total annual landings biomass and first-sale value of the fishery (INE, 2011). Since 1986, Portuguese landings of chub mackerel ranged between 4000 and $23000 \mathrm{t}$ (between $727 \mathrm{t}$ and $40000 \mathrm{t}$ in earlier years since 1958), varying broadly inversely with sardine landings (Fig. 1). Landings were high from the mid-1960s to the mid-1970s, fluctuated at a low level (ca. 10000 t per year) until the early 2000s and increased subsequently. Since then, chub mackerel landings represent around 10\% of the total purse seine landings. Most of the landings are for human consumption as fresh and canned products (INE 2011). In recent years, a small amount is used for tuna feeding in an aquaculture farm located off the southern coast (P. Pousão-Ferreira, pers. comm.).

As is typical of small and medium-sized pelagic species, Pacific chub mackerel experience cyclical periods of abundance (Suda et al. 2008, Crone et al. 2011 and references therein). Temperature seems to play an important role in the recruitment success of

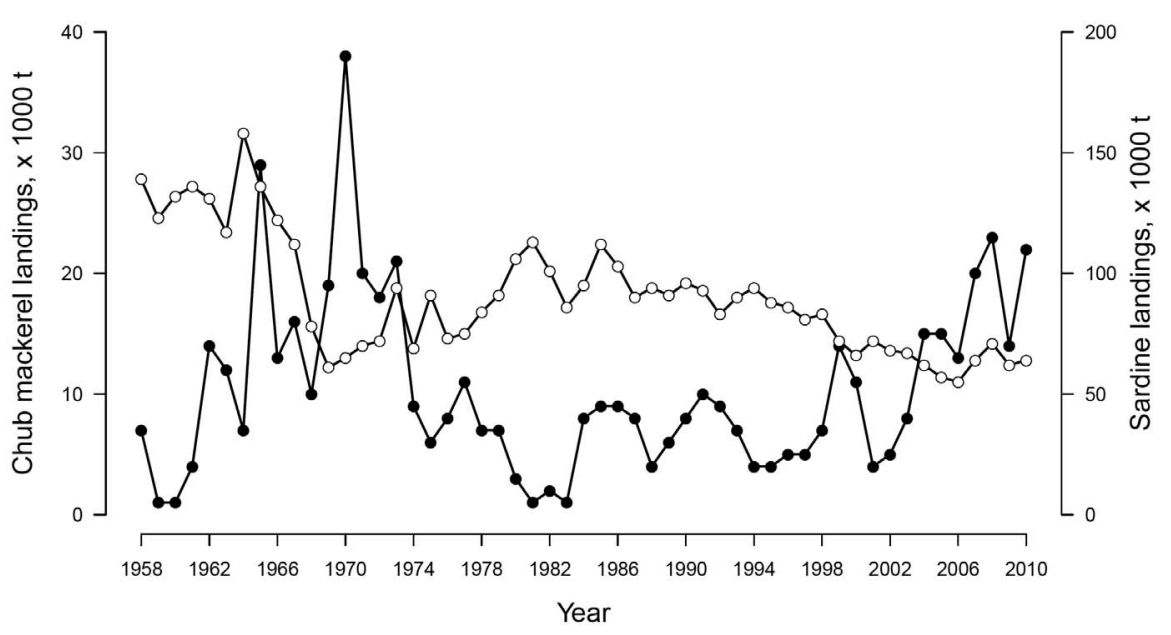

FIG. 1. - Historical landings of chub mackerel (solid circles) and sardine (open circles) in Portugal. 
TABLE 1. - Presence (in percent of trawl hauls) and length range of chub mackerel and abundance of sardine (numbers) in acoustic surveys 1995-2010.

\begin{tabular}{|c|c|c|c|c|c|c|}
\hline \multirow[b]{2}{*}{ Year } & \multirow[b]{2}{*}{ Season } & \multirow[b]{2}{*}{ Number of trawl hauls } & \multicolumn{3}{|c|}{ Chub mackerel } & \multirow[b]{2}{*}{$\begin{array}{l}\text { Sardine abundance } \\
\qquad\left(\times 10^{6}\right)\end{array}$} \\
\hline & & & Presence $(\%)$ & $\begin{array}{l}\text { Length range } \\
(\mathrm{cm})\end{array}$ & $\begin{array}{l}\text { Number } \\
\text { sampled }\end{array}$ & \\
\hline 1995 & spring & 30 & 50 & $15-42$ & 953 & 10.5 \\
\hline 1996 & spring & 21 & 52 & $16-42$ & 1190 & 9.4 \\
\hline 1996 & summer & 34 & 65 & $16-34$ & 1082 & 6.0 \\
\hline 1997 & spring & 40 & 48 & $18-26$ & 866 & 14.0 \\
\hline 1997 & autumn & 34 & 50 & $16-49$ & 962 & 8.2 \\
\hline 1998 & spring & 40 & 55 & $14-26$ & 2157 & 11.4 \\
\hline 1998 & autumn & 48 & 38 & $17-26$ & 692 & 21.2 \\
\hline 1999 & spring & 28 & 36 & $18-29$ & 886 & 11.6 \\
\hline 1999 & autumn & 19 & 26 & $21-55$ & 113 & 7.9 \\
\hline 2000 & spring & 29 & 31 & $22-34$ & 88 & 11.9 \\
\hline 2000 & autumn & 41 & 17 & $21-30$ & 68 & 36.0 \\
\hline 2001 & spring & 43 & 16 & $21-29$ & 277 & 20.8 \\
\hline 2001 & autumn & 32 & 16 & $20-32$ & 28 & 25.3 \\
\hline 2002 & spring & 37 & 8 & $22-23$ & 3 & 20.7 \\
\hline 2003 & spring & 23 & 22 & $20-26$ & 121 & 13.3 \\
\hline 2004 & summer & 15 & 20 & $16-27$ & 70 & 11.6 \\
\hline 2005 & spring & 40 & 58 & $9-34$ & 1314 & 25.2 \\
\hline 2005 & autumn & 28 & 54 & $16-30$ & 666 & 17.8 \\
\hline 2006 & spring & 38 & 74 & $17-34$ & 1987 & 16.5 \\
\hline 2006 & autumn & 26 & 81 & $16-37$ & 2319 & 8.1 \\
\hline 2007 & spring & 47 & 79 & $13-38$ & 3391 & 8.9 \\
\hline 2007 & autumn & 20 & 85 & $11-34$ & 2516 & 7.4 \\
\hline 2008 & spring & 49 & 73 & $7-37$ & 2085 & 7.0 \\
\hline 2008 & autumn & 29 & 90 & $15-31$ & 2181 & 8.1 \\
\hline 2009 & spring & 35 & 71 & $16-31$ & 1304 & 9.5 \\
\hline 2010 & spring & 24 & 79 & $11-32$ & 1045 & 8.9 \\
\hline
\end{tabular}

both species of chub mackerel. Higher temperatures, often related to weak upwelling, are considered favourable to spawning and productivity of chub mackerel off South Africa (Crawford 1983), northwest Africa (Cury and Roy 1987), Japan (Yatsu et al. 2005) and the California Current System (Parish and MacCall 1978). In some regions, booms and bursts of chub mackerel species at decadal scales were part of global changes often associated with environmental regime shifts affecting pelagic ecosystems (Castro-Hernández and Santana-Ortega 2000 and references therein). Species replacements may take place, mainly between sardine and anchovy but sometimes involving less abundant species of pelagic ecosystems like chub mackerel in the Pacific (e.g. Alheit et al. 2009). An illustrative example is that of the pelagic ecosystem off the Japanese waters: Pacific sardine and anchovy have shown dramatic out-of-phase fluctuations in abundance since the 1940 s, leading to an anchovy period up to the late $1960 \mathrm{~s}$ and a sardine period in the 1980s, with another shift in the 1990s (Yatsu et al. 2005, Watanabe 2009). The saury (Cololabis saira) and jack mackerel (Trachurus japonicus) populations seem to be in synchrony with anchovy, whereas Pacific chub mackerel increased in the early 1970s, as anchovy and saury declined and sardine had not recovered yet.

Data on the population dynamics and role of chub mackerel in the pelagic ecosystem off Atlantic Iberian waters are limited, precluding a better understanding of the ecosystem functioning and a more rational management of the purse seine fishery. In Portugal, interest in chub mackerel has grown in recent years due to the perception, shared by fishermen and scientists, of a concurrent increase of its availability and decrease in sardine abundance. In this paper, using data from acoustic surveys since 1995 and the fishery since 1986 , we examine changes in abundance and in the spatial distribution of chub mackerel in the Portuguese waters and the Spanish waters of the Gulf of Cadiz (hereby termed Portuguese-Cadiz waters). We compare the distribution, abundance, recruitment and landings of chub mackerel and sardine and discuss interactions between the two species.

\section{MATERIALS AND METHODS}

\section{Survey and fishery data}

Data on the presence and length composition of chub mackerel in trawl hauls was recorded in 26 acoustic surveys conducted by the Instituto Português do Mar e Atmosfera (IPMA) between 1995 and 2010 (Table 1). Estimates of chub mackerel abundance, length and age composition, in number and biomass, were obtained only in acoustic surveys in the autumn of 2007, spring and autumn 2008 and spring 2009. The surveys cover the continental shelf off the Portuguese-Cadiz waters (Fig. 2) from 15 to $200 \mathrm{~m}$ depth. The main aim of the surveys is to estimate the biomass and length/age structure of sardine and anchovy for stock assessment purposes (e.g. ICES 2011b, c). Although pelagic species other than sardine and anchovy are not the target of the acoustic surveys, biological samples of chub mackerel have been regularly collected whenever it occurs in trawl hauls. The acoustic surveys do not cover the shelf break and upper slope where larger chub mackerel are 


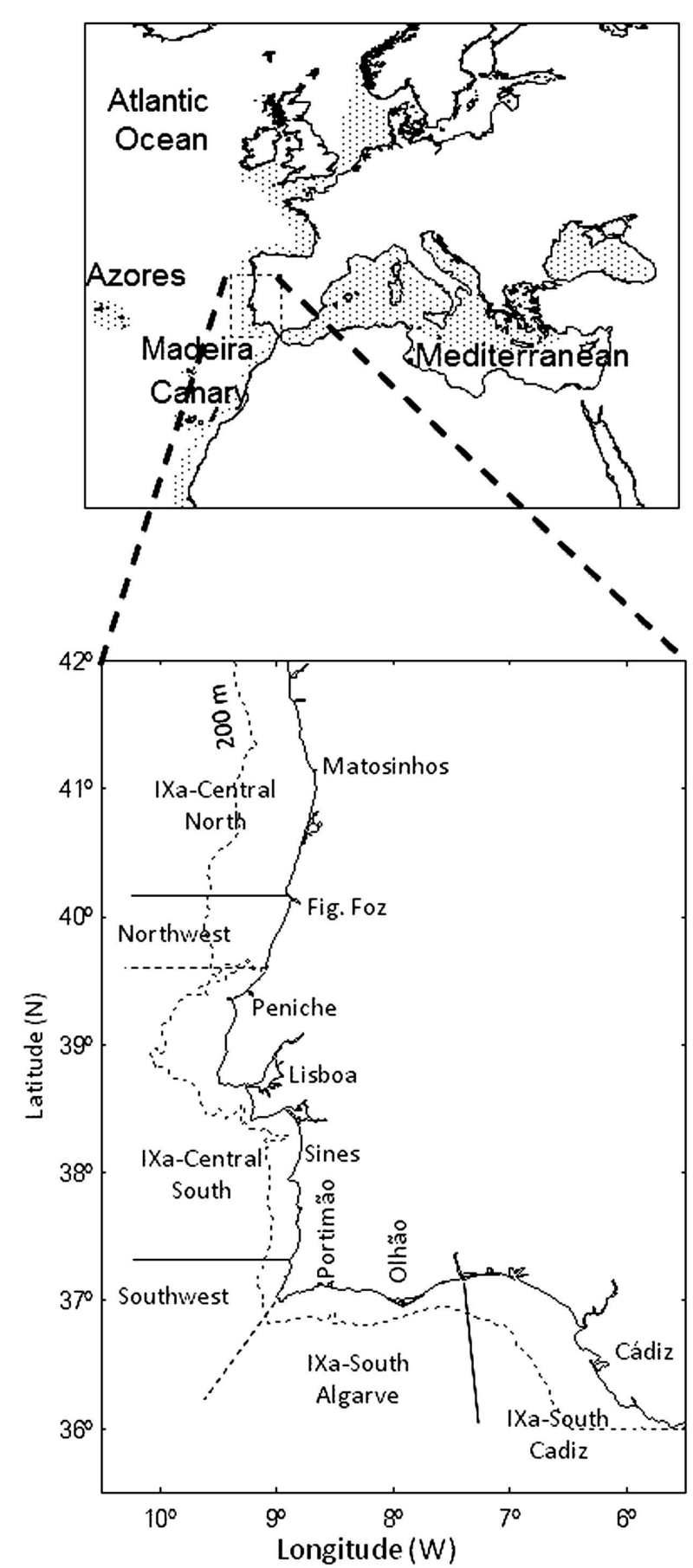

FIG. 2. - Map of the study area showing the location of the main sampling ports, ICES sub-divisions and acoustic survey sub-areas. Off the west coast, continuous and dashed lines show the boundaries of ICES sub-divisions and survey sub-areas, respectively.

known to be distributed. Nevertheless, the component of the population distributed on the shelf, mostly young individuals, is considered to be well sampled.

The survey area is divided into four sub-areas for which separate estimates of abundance and length/ age composition are provided: northwest, southwest, south-Algarve and south-Cadiz (Fig. 2). Off the south
TABLE 2. - Summary of the sampling effort per year of chub mackerel landings.

\begin{tabular}{lcccc}
\hline & $\begin{array}{c}\text { Number of } \\
\text { samples }\end{array}$ & $\begin{array}{c}\text { Number of } \\
\text { fish sampled }\end{array}$ & Range & Mean \pm SD \\
\hline Length $(\mathrm{cm})$ & $119 \pm 26$ & $1146 \pm 453$ & $12-65$ & $27.3 \pm 6$ \\
Age (years) & $13.5 \pm 3.9$ & $408 \pm 106$ & $0-11+$ & $2.3 \pm 2.2$ \\
\hline
\end{tabular}

coast, sub-areas match the ICES sub-divisions IXa South-Algarve and IXa South-Cadiz. Off the west coast the north-south boundary considered in the surveys is located slightly south of the boundary between ICES sub-divisions IXa Central-North and IXa Central-South.

For the estimation of fish abundance, acoustic samples were continuously taken during daytime at a rate of 1 ping s ${ }^{-1}$ along parallel transects $8 \mathrm{nmi}$ apart (ICES 1998) by means of a calibrated (Foote et al. 1987), 38-kHz Simrad EK500 echosounder with a split beam transducer (equivalent beam angle: $10 \log =-20.2 \mathrm{~dB}$; pulse duration $=1 \mathrm{~ms}$ ). Acoustic data were acquired and stored on a personal computer and post-processed using the software MOVIES+ (Weill et al. 1993). The echograms were visually scrutinized for echoes of fish schools, and the resulting backscatter was integrated from $1 \mathrm{~m}$ above the bottom to 4 $\mathrm{m}$ below the surface, and averaged along $1 \mathrm{nmi}$ long intervals. Biological samples for echo classification and characterization of the pelagic fish community were taken mainly by a midwater trawl with the aid of a Netsounder (Scanmar trawl-eye and depth sensor), towed at speeds of 3.5-4.5 knots. Sometimes a bottom trawl was used to fish near the bottom. Trawl stations were directed at echo traces with importance in terms of acoustic backscatter and potential species composition. The average target strength (TS) was derived according to the formula: $\mathrm{TS}=20 \log (\mathrm{L})-\mathrm{b} 20(\mathrm{~dB})$, where length $\mathrm{L}(\mathrm{cm})$ was derived from length compositions taken from the nearest trawl and b20 $=68.7$ for chub mackerel and 72.6 for sardine (ICES 2009). For each species, samples of 100 individuals were taken randomly from each trawl haul and sorted in classes of $0.5 \mathrm{~cm}$ (sardine) or $1 \mathrm{~cm}$ (chub mackerel) total length. Age-length keys were obtained from length-stratified samples by sub-area in each survey. Age determination was carried out on sub-samples of 10 individuals per length class.

To calculate species abundances, the pelagic fish acoustic backscatter was partitioned into species, taking into account the proportion of the species in the fishing trawls and the specific acoustic target strength/ length relationship of the involved species (further details in Zwolinski et al. 2009 and ICES 2010). Estimates of chub mackerel abundance in 2007-2009 are reported for the first time in the present paper. Those of sardine were compiled from several ICES reports (e.g. ICES 2011c).

Portuguese annual landings of chub mackerel and sardine by ICES sub-division were compiled from the database of the Portuguese General Directorate 
TABLE 3. - Abundance of chub mackerel by sub-area in the Portuguese acoustic surveys 2007-2009, in biomass ( $\times 1000 \mathrm{t}$, bold text) and number of individuals (millions). Data are pooled for the northwest and southwest areas in all surveys apart from Spring 2009 and for the southern areas (Algarve and Cadiz) in Spring 2008. In Autumn 2007, the estimate of the northwest area includes the southwest area until Lisbon; the southwest area south of Lisbon and the west part of south Algarve are not covered.

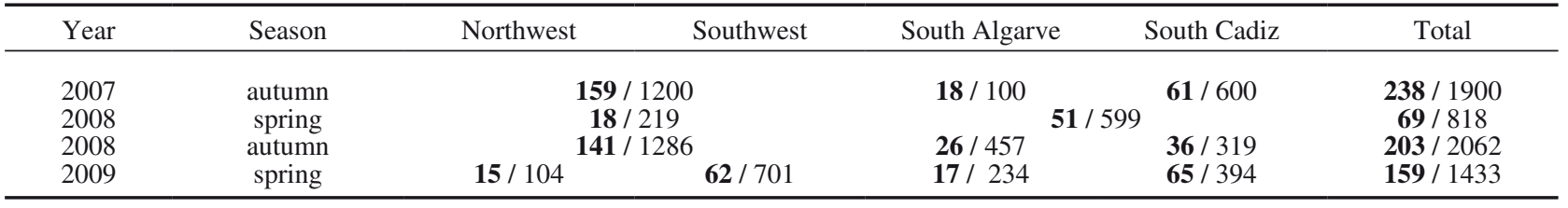

of Fisheries (e.g. DGPA 2011). Length and age data were collected within the framework of national sampling programmes integrated in EU data collection programmes. The collection of length data follows a stratified random sampling scheme by gear, port and quarter, the sampling unit being the trip. Age data are collected following a similar sampling scheme with ICES sub-division and length class (as defined above) as strata and the individual as the sampling unit. Details on the sampling and raising methods to estimate length and age distributions of the landings are found in Jardim et al. (2004). Table 2 summarizes the sampling effort in the period 1986-2010.

\section{Statistical analysis}

To evaluate changes in the prevalence of chub mackerel on the Portuguese continental shelf, the probability of chub mackerel presence in trawl hauls (p) was modelled as a function of sub-area (a), year (y), and sardine abundance (in numbers, $\mathrm{nS}$ ) using generalized additive models (GAM) with a binomial error distribution and a logit link (Wood, 2006). A smooth function (s(.)) was used to describe the year effect, and the effects of sub-area and sardine abundance were described by parameters. Both year and sardine abundance were assumed to vary by sub-area in the initial model. The general form of the model is:

$$
\operatorname{Logit}(E[p])=a+s(y) * a+n S * a
$$

Model selection was conducted by log-likelihood ratio tests (LRT, Wood 2006). The results of LRT tests were examined for consistency with the minimization of the Akaike Information Criterion (AICc, corrected AIC for small sample sizes). Sub-areas with less than four trawl hauls were not included in the model.

Models assuming that the effects of year and of sardine abundance were common to all areas were examined, i.e. terms $\mathrm{s}(\mathrm{y})^{*} \mathrm{a}$ and $\mathrm{nS}^{*} \mathrm{a}$ of the initial model were sequentially replaced by $\mathrm{s}(\mathrm{y})$ and $\mathrm{nS}$. Finally, some area levels were pooled, first southwest and south, then Cadiz was pooled with former levels to investigate regional differences in the average prevalence of chub mackerel.

To explore the relative strength of year classes, standardized proportions-at-age, $\mathrm{P}_{\mathrm{ay}(\mathrm{s})}$, were calculated from the commercial catch-at-age matrix, in numbers, in 1986-2010, as follows:

$$
\mathrm{P}_{\mathrm{ay}(\mathrm{s})}=\left\{\mathrm{P}_{\mathrm{ay}}-\mathrm{P}_{\mathrm{a}}\right\} / \mathrm{s}_{\mathrm{a}}
$$

where $\mathrm{P}_{\mathrm{ay}}$ is the proportion of catch of age a in year $\mathrm{y}$, $\mathrm{P}_{\mathrm{a}}$ is the mean and $\mathrm{s}_{\mathrm{a}}$ the standard deviation of the proportion of age a over years. $\mathrm{P}_{\mathrm{ay}}$ is obtained by dividing the catch of age a and year $y$ by the total catch in year $y$, being therefore independent of year-to-year variations in the total amount of catches. The plot of $\mathrm{P}_{\mathrm{ay}(\mathrm{s})}$ shows the importance of year classes as anomalies from the mean and is therefore useful to outline relatively strong and weak year classes.

\section{Recruitment index}

Using the catch-at-age matrix, in numbers, in 19862010 we calculated the geometric mean of catches over ages 0 to 2 years for each year class. This quantity was considered to be a broad index of chub mackerel recruitment. It was normalized by subtracting the mean to compare with an index of sardine recruitment.

Unlike $\mathrm{P}_{\mathrm{ay}(\mathrm{s})}$, the chub mackerel recruitment index is affected by the total amount of catches over time although the use of the geometric mean is expected to smooth out differences among years. Moreover, a change in fishing effort or natural mortality will bias the index.

\section{RESULTS}

\section{Acoustic surveys}

Presence/absence data since 1995 and estimates of abundance (2007-2009) in acoustic surveys show that chub mackerel is distributed mainly off the southwestern and southern waters of the Iberian Peninsula (Table 3, Figs 3, 4A). In general, chub mackerel abundance was the lowest in south Algarve, intermediate in the Gulf of Cadiz and higher in the western area (Table 3). In the latter area, most of the biomass is found south of Lisbon, except in autumn 2007 (Fig. 4A).

The geographical distribution changes between years (Fig. 4A). Up to the mid-2000s, chub mackerel occurred more frequently off the eastern part of the south coast (Gulf of Cadiz) than off the joint southwest and south Algarve area (Fig. 3). In the mid-1990s and mid-2000s, the distribution extended to the north (Fig. 3) and in 2007 great abundance was found towards the northern limit of the distribution area (Fig. 4A). In 2007-2009, chub mackerel biomass on the survey area ranged from 


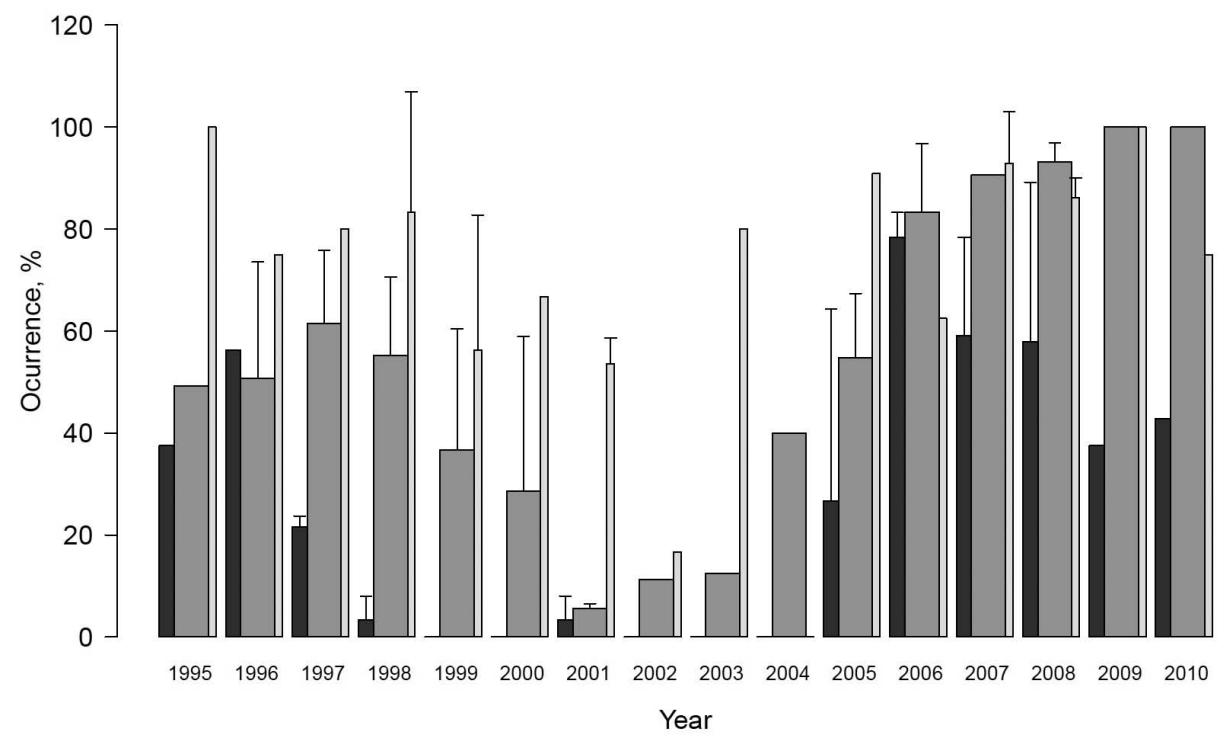

FIG. 3. - Occurrence of chub mackerel in fishing hauls in acoustic surveys covering the Portuguese waters and the Gulf of Cadiz in the period 1995-2010. Northwest, black bars; southwest and south Algarve, dark grey bars; South-Cadiz, light grey bars. Width of the bars proportional to the number of trawls in the area. Segments represent standard deviations between seasons for each year and sub-area. Sub-areas with fewer than four trawl hauls not included.

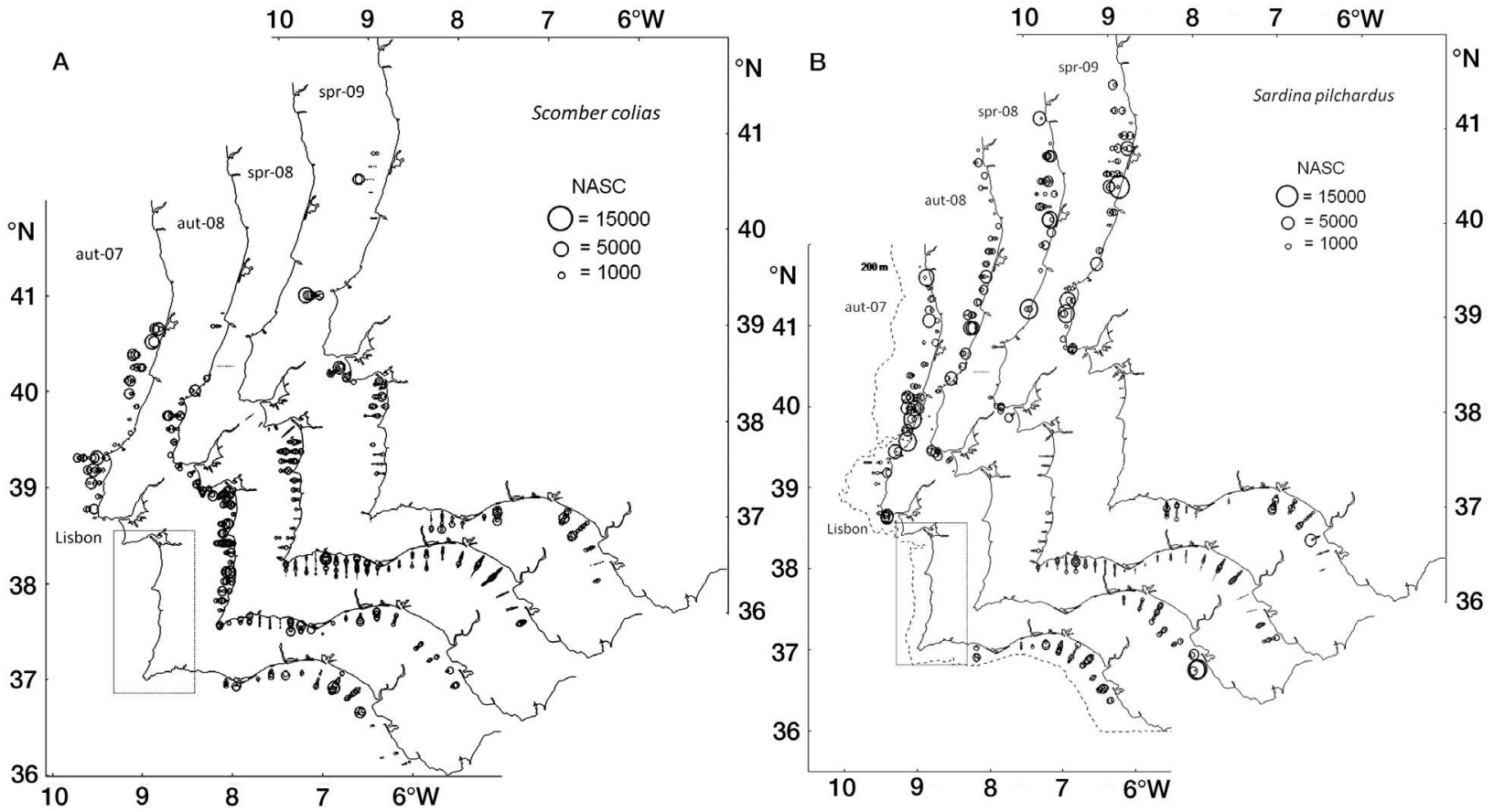

FIG. 4. - Chub mackerel (A) and sardine (B) distribution in acoustic surveys 2007-2009 (two autumn and two spring surveys). Scale shows nautical area scattering coefficient (NASC) units, SA m²/nm². In the autumn 2007 survey the southwestern area south of Lisbon was not covered.

$69000 \mathrm{t}$ to $238000 \mathrm{t}$, being larger in the autumn surveys when recruits (0-group) are caught (Table 3 ). The highest biomass estimate obtained in autumn 2007 is likely to be an underestimate since the survey did not cover the main parts of chub mackerel distribution (southwest and the western part of south Algarve).

The spatial distribution of chub mackerel overlaps with that of sardine across most of the Portuguese waters (Fig. 4A, B). This overlap is more extensive and consistent off the southern than off the western coasts; off the latter, chub mackerel occurs more frequently and in higher abundance south of Peniche-Lisbon $\left(38-39^{\circ} \mathrm{N}\right)$, whereas the opposite is true for sardine. Figures $4 \mathrm{~A}$ and $4 \mathrm{~B}$ also show that chub mackerel extends further offshore than sardine. The frequency of occurrence of chub mackerel in the survey area shows a weak negative correlaton with the abundance of sardine (Spearman rho $=-0.51, \mathrm{p}<0.008, \mathrm{n}=26)$. 
TABLE 4. - Initial and final generalized additive model fit to chub mackerel presence/absence data in acoustic surveys 1995-2010.

\begin{tabular}{|c|c|c|c|c|c|c|}
\hline \multirow{2}{*}{ Model } & \multicolumn{3}{|c|}{ Parametric terms } & \multicolumn{3}{|c|}{ Smooth terms } \\
\hline & Name & Coefficient & $\mathrm{p}$ & Name & Edf & $\mathrm{p}$ \\
\hline \multirow[t]{8}{*}{ Initial } & Northwest & -1.0 & 0.33 & Year $\times$ Northwest & 2.6 & 0.23 \\
\hline & Southwest & 1.7 & 0.26 & Year $\times$ Southwest & 2.0 & 0.25 \\
\hline & South-Algarve & 2.2 & 0.18 & Year $\times$ South-Algarve & 2.1 & 0.24 \\
\hline & South-Cadiz & 3.2 & 0.04 & Year × South-Cadiz & 1.0 & 1.00 \\
\hline & Northwest $\times \mathrm{nS}$ & $-3.9 \mathrm{E}-08$ & 0.77 & & & \\
\hline & Southwest $\times \mathrm{nS}$ & $-2.1 \mathrm{E}-07$ & 0.55 & & & \\
\hline & South-Algarve $\times \mathrm{nS}$ & $-4.2 \mathrm{E}-07$ & 0.68 & & & \\
\hline & South-Cadiz $\times$ nS & $-3.0 \mathrm{E}-07$ & 0.25 & & & \\
\hline \multirow{3}{*}{ Final } & Northwest & -1.3 & 0.016 & Year & 3.3 & 0.001 \\
\hline & Southwest + South-Algarve & 1.5 & 0.015 & & & \\
\hline & South-Cadiz & 2.6 & 0.001 & & & \\
\hline
\end{tabular}
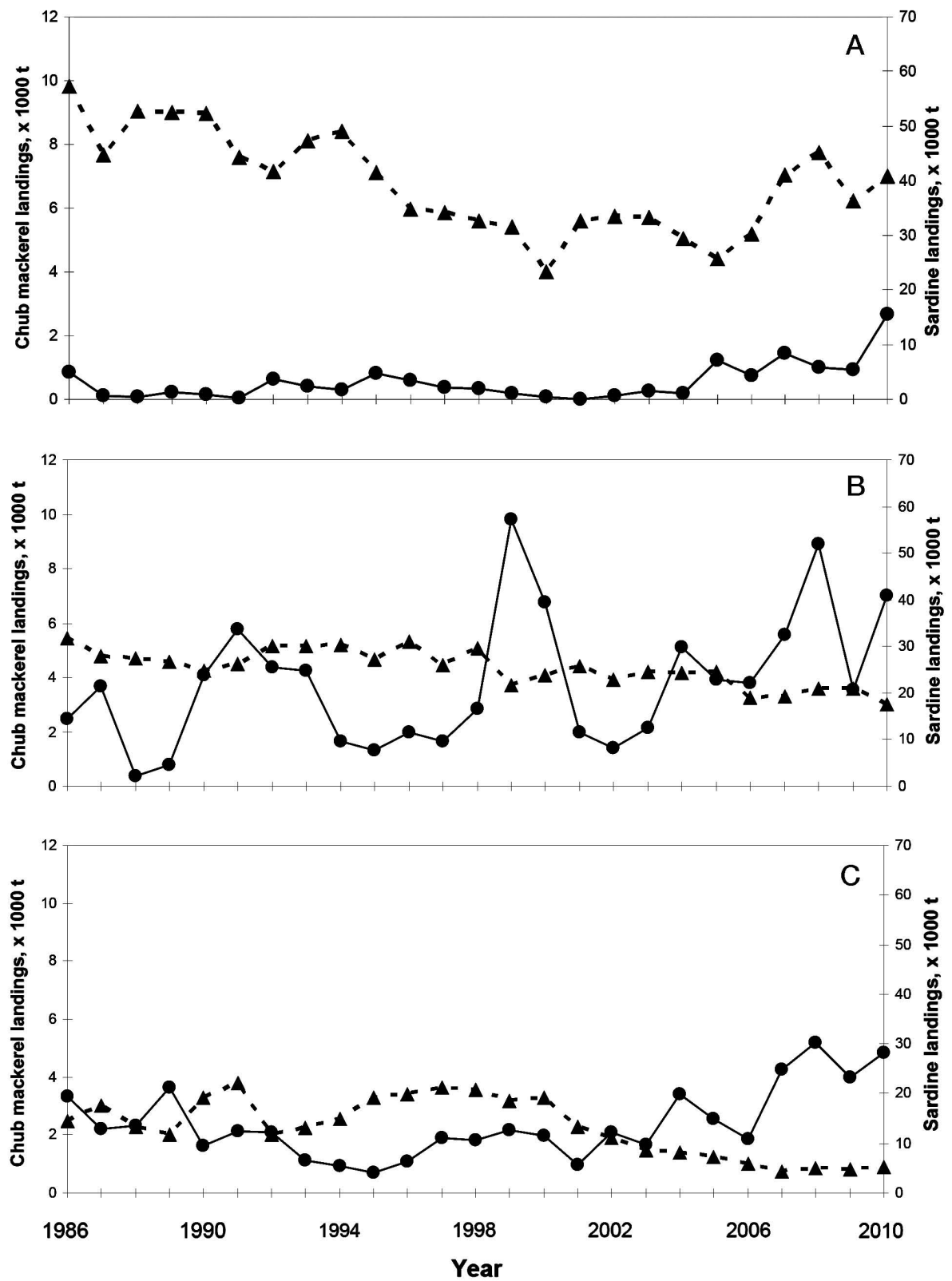

FIG. 5. - Purse seine landings of chub mackerel (solid line) and sardine (dashed line) off northwest (A), southwest (B) and south Algarve (C) in the period 1986-2010. 
TABLE 5. - Abundance-at-age of chub mackerel, in millions of individuals, in acoustic surveys 2007-2009. The $10 \%$ and $90 \%$ quantiles of length in each survey are also shown. Shaded cells identify year classes.

\begin{tabular}{|c|c|c|c|c|c|c|c|}
\hline \multirow[t]{2}{*}{ Year } & \multirow[t]{2}{*}{ Season } & \multicolumn{4}{|c|}{ Age group (years) } & \multicolumn{2}{|c|}{ Length quantiles $(\mathrm{cm})$} \\
\hline & & 0 & 1 & 2 & 3 & $10 \%$ & $-90 \%$ \\
\hline 2007 & autumn & 829 & 1131 & 4 & & $19.5-$ & -23.5 \\
\hline 2008 & spring & & 570 & 245 & 1 & 20.5 & -24.5 \\
\hline 2008 & autumn & 830 & 1228 & 3 & & 16.5 & -23.5 \\
\hline 2009 & spring & & 945 & 464 & & $17.5-$ & -24.5 \\
\hline
\end{tabular}

Table 4 shows the parameters of the initial and final GAM fit to the presence/absence data. AICc decreased from 137.5 to 96.5 (41 units) and the percentage of deviance explained decreased from $69 \%$ to $65 \%$ from the initial to the final model. The analysis indicates that the presence of chub mackerel varied in space and time during the period 1995-2010 but was not affected by the abundance of sardine. The number of sardines had no significant effect on the presence of chub mackerel, either when a common area effect was assumed or when separate area effects were modelled. To examine whether the poor explanatory power of sardine abundance could be due to collinearity with the year effect, a model excluding the variable year was also fitted to the data (not shown). The abundance of sardine was again not significant and the model explained a much lower percentage of the deviance than the model including year.

The presence of chub mackerel in acoustic trawl hauls increases significantly from north to south and is comparable in the southwest and south Algarve sub-areas (Table 4). Over the study period, mean probabilities of presence in each area were $27.6 \pm 22.1 \%$ off the northwest coast, $55.9 \pm 24.7 \%$ in the southwest-south Algarve region and $74.7 \pm 18.1 \%$ in the Gulf of Cadiz. Changes over time were not significantly different among areas: the single smooth term of year shows a decline in chub mackerel presence from the mid-1990s to the early 2000s and thereafter an increase to values exceeding those at the beginning of the period. For example, in the southwest-south region, chub mackerel occurred in $c a$. $60 \%, 23 \%$ and $90 \%$ of the trawl hauls in 1995-1997,
2001-2002 and 2008-2010, respectively. The GAM results also point to a shallower time variation in the Gulf of Cadiz than in the southwest-south region.

The total length of fish sampled in surveys since 1995 ranges between 7 and $55 \mathrm{~cm}$. However, the majority of the individuals are between 20 and $24 \mathrm{~cm}$. In 2007-2009, when length frequency distributions were available at the population level, the $10 \%$ and $90 \%$ percentiles of length were in the range $16.5-20.5 \mathrm{~cm}$ and $23.5-24.5 \mathrm{~cm}$, respectively. The age groups 0-1 years and 1-2 years predominated in the autumn and spring surveys, respectively (Table 5). Fish older than 3 years (up to age 7) occurred only in spring 2008 off the south coast.

\section{Fisheries}

In the period 1986-2010 total chub mackerel landings varied between 4000 and $23000 \mathrm{t}$ (mean $\pm \mathrm{SD}$ $=10 \pm 6$ thousand $\mathrm{t}$; Fig. 1). On average, $69 \%$ of the annual landings were taken in the purse seine fishery, $27 \%$ in multi-gear artisanal fisheries (operating with longlines, gill nets and trammel nets) and $4 \%$ in the bottom trawl fishery. Landings by purse seiners are recorded mainly on the southwest coast (3800 t, 54\%), followed by the south coast $(2400 \mathrm{t}, 38 \%)$ with only a small quantity of chub mackerel being landed in the ports of the northwest area $(550 \mathrm{t}, 8 \%)$.

Since 2003, total landings have increased consistently, reaching $23300 \mathrm{t}$ in 2008 (Fig. 1). Temporal variation shows some differences among areas: in the southwest, there were both abrupt fluctuations between years and an increasing trend since 1986; in the south,

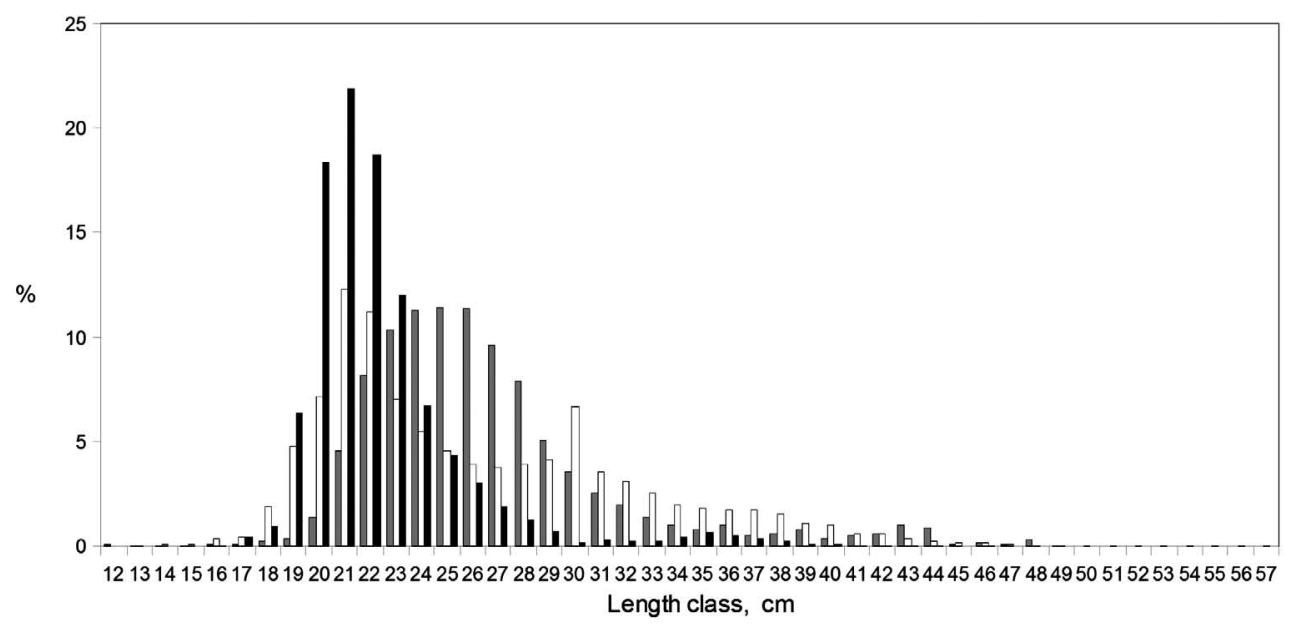

FIG. 6. - Length frequency distributions of chub mackerel in landings by purse seiners (black bars), artisanal boats (white bars) and trawlers (grey bars). The percentages are calculated within each fishery from average annual length frequency distributions in 1986-2010. 
landings declined from 1986 to the early 2000s and increased sharply thereafter and, in the north, a sharp increase took place in the mid-2000s after a long period of low fluctuating landings (Fig. 5).

Landings of chub mackerel and sardine broadly reflect their spatial distributions: chub mackerel is fished mainly in the south and southwestern areas, while sardine is fished mainly in the northwest area (Fig. 5). Landings of chub mackerel and sardine in the southwest and southern areas were negatively correlated (Spearman rho $=-0.48$ and $-0.57, \mathrm{p}=0.016$ and 0.003 , respectively, $n=25)$ while in the northwest area they were not correlated (Spearman rho $=-0.04, \mathrm{p}=0.86, \mathrm{n}=25$ ).

Most of the individuals landed by the purse seine fishery are between 18 and $26 \mathrm{~cm}$; the length distribution shows a single mode at $21 \mathrm{~cm}$ and a long right tail reaching $49 \mathrm{~cm}$ (Fig. 6). Artisanal landings comprise a wider range of lengths, from 13 to $57 \mathrm{~cm}$; the length distribution has two modal classes of decreasing importance, $21 / 22$ and $30 \mathrm{~cm}$, possibly corresponding to different fishing gears. Part of the artisanal fleet ( $\mathrm{ca}$. 200 small vessels below $15 \mathrm{~m}$ length) is allowed to operate with a purse seine and occasionally land small pelagics (INE 2011). The lower lengths ( 1-3 years old) in landings possibly correspond to chub mackerel caught by artisanal purse seiners, while larger individuals ( $\sim 5-6$ years old) are usually caught in the other gears which operate in deeper areas. Bottom trawlers land chub mackerel with $21-31 \mathrm{~cm}$ mostly. Landings are composed mainly of age 1 to 3 individuals although fish up to 13 years occur.

Despite some noise in the data, the age composition of landings does not show major changes over time and year classes can generally be followed in the standardized catch-at-age matrix (Fig. 7). The 1996, 2002 and 2007 year classes stand out, showing consistent above average proportions in the younger ages. Large pro-

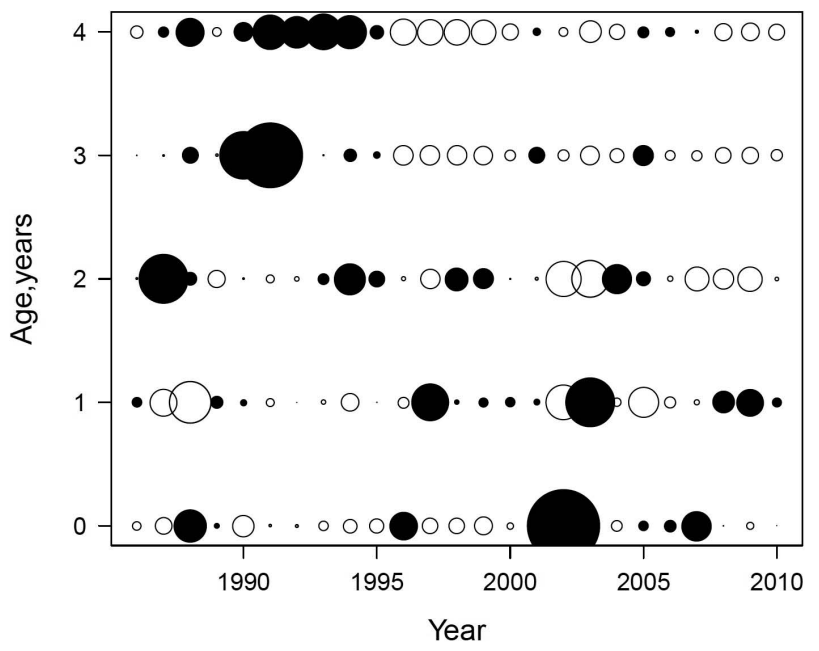

FIG. 7. - Standardized catch-at-age proportions (in numbers) of chub mackerel in 1986-2010. Black symbols correspond to positive deviations and white symbols to negative deviations from the mean proportion-at-age over the period.

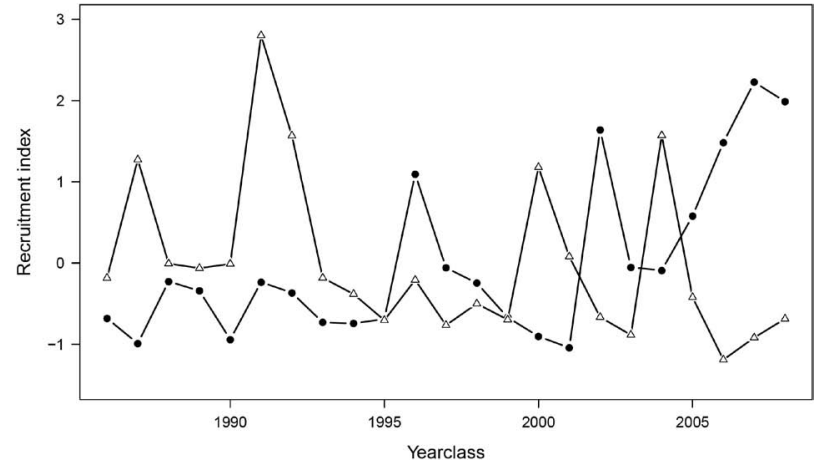

FIG. 8. - Chub mackerel (circles) and sardine (triangles) recruitment indices (normalized) in 1986-2008. The series of sardine recruitments is from the 2012 stock assessment (ICES, 2012).

portions of ages 3-4 years in the earlier years of the catch-at-age matrix suggest that some year classes in the late 1980s might have been relatively strong. However, it may also reflect that the fishery selected older individuals in those years.

The recruitment index broadly agrees with the relative age composition $\left(\mathrm{P}_{\mathrm{ay}(\mathrm{s})}\right)$ information on year-class strength although it suggests a higher relative strength of recent year classes (2006-2008) (Fig. 8). This increase may be biased by the sharp increase of landings in 2007-2010. The index suggests a period of low recruitment from 1986 to 1995 and in 2000-2001. Thereafter, recruitment shows a tendency to increase and reaches a historical maximum in 2007. The presence of chub mackerel in the spring surveys each year is positively correlated with the recruitment index the year before (Spearman $r h o=0.58, \mathrm{p}<0.03, \mathrm{n}=15$ ). However, the large 2002 recruitment index is not reflected in the occurrence of chub mackerel in the next spring survey (Table 1 and Fig. 8). When this data point is excluded, the correlation coefficient increases to $0.72(p<0.005)$. Finally, the normalized indices of chub mackerel and sardine recruitment show a significant negative correlation $($ Spearman rho $=-0.53, \mathrm{p}=0.01, \mathrm{n}=23$ ).

\section{DISCUSSION}

Data from acoustic surveys and the purse seine fishery off Portugal and the Gulf of Cadiz show that chub mackerel is mainly distributed off the southwestern and southern waters from Lisbon to the Gibraltar Strait. In 1995-2010, chub mackerel occurred consistently in the Portugal-Cadiz region, being present on average in $50 \%(\mathrm{sd}=25 \%)$ of the trawl hauls in each survey. It showed comparable frequencies off the Portuguese southwest and southern waters and occurred significantly more often in the Gulf of Cadiz. In recent years (2007-2009) the biomass ranged from $69000 \mathrm{t}$ (818 million individuals) to $238000 \mathrm{t}$ (1900 million individuals). Biomass estimates for northern Spain in spring 2008 and 2009 were 5\% and 3\% of the estimates in the Portugal-Cadiz region in corresponding years (ICES 2008, 2009), suggesting that the latter region 
encompasses the bulk of chub mackerel distributed in Atlantic Iberian waters. About $50 \%$ of the biomass is distributed in the western Portuguese waters and 30\% in the Gulf of Cadiz. Biomass estimates for Cadiz in 2007 and 2009 are consistent with those obtained in the Spanish acoustic survey covering the area in summer in the same years, (62000 and 56000 t; ICES 2009, 2010). Data from Portuguese acoustic surveys in 20072009 show that chub mackerel biomasses in the Portugal-Cadiz region were $1 / 3$ to $2 / 3$ of the biomasses of sardine in corresponding surveys, indicating that chub mackerel was an important component of the pelagic community in those years. Given that chub mackerel increased and sardine decreased in recent years, the relative importance of chub mackerel is possibly at the highest level since 1995.

Up to the present, groundfish surveys (Martins and Cardador 1996, Sousa et al. 2005) have been the only source of survey data on chub mackerel distribution off Portugal. This type of survey is not designed to sample pelagic species and is likely to provide underestimates of their abundance. Pelagic species such as chub mackerel might be accidentally caught when the trawl is being retrieved (Pequerie et al. 2004). Furthermore, like most small and medium-sized pelagics, chub mackerel exhibit demersal behaviour as well (Sousa et al. 2005). The Portuguese groundfish surveys cover deeper waters than acoustic surveys and we consider that they provide useful complementary information on the distribution chub mackerel. The geographical distribution observed in the present study is broadly in agreement with that reported by Martins and Cardador (1996) and Sousa et al. (2005) based on groundfish surveys data. Martins and Cardador (1996) show a consistently higher abundance off the south western area in the period 1990-1995, with average numbers-per-hour double those off south Algarve. This pattern is in agreement with the distribution of biomasses in 2007-2009 acoustic surveys; thus, despite similar frequency of occurrence, chub mackerel is probably more abundant off the southwest than off the south Algarve area, in consistency with the level of landings in the two areas. Higher abundance in autumn than in spring, reflecting recruitment (0-group), was also found by Martins and Cardador (1996).

The model fit to presence/absence data in the period 1995-2010 show that chub mackerel was more frequent in the Portuguese-Cadiz waters during the second half of the 1990s and particularly since the mid-2000s. In these periods the population expanded to the northwestern area, where the species is normally scarce. The frequency of occurrence appears to be a good proxy of abundance since it coincides well with recruitment strength, with a single exception, the 2002 year class. The reason why the 2003-2004 surveys missed the 2002 year class is not clear. However, the frequency of occurrence of chub mackerel in the Gulf of Cadiz rose sharply in 2003 and landings off the southwestern and southern areas show a peak in 2004. The rise in landings, off both northern Portugal and Galicia (ICES 2011a), support the hypothesis of an increase in abundance and an expansion of the distribution area to the north in the recent period. This did not happen in the mid-1990s off northern Portugal. Other factors such as targeting by the fishery in recent years due to the appearance of new markets (e.g. for tuna feeding) and lower abundance of sardine might have contributed to the recent rise in landings.

Both the acoustic surveys and the purse seine fishery show a predominance of small individuals (20-24 $\mathrm{cm}$ and 1-2 years old), in the study area. However, larger/older individuals (50-55 cm and 7-10 years old), are occasionally sampled in surveys and small numbers are landed in longline, gillnet and bottom trawl fisheries. The scarceness of large chub mackerel may reflect their absence from the Portugal-Cadiz waters or a low availability of large individuals to the acoustic survey and purse seine fishery.

One hypothesis is that the Portugal-Cadiz waters are a nursery of a large population spawning north or, more likely, in Moroccan waters, where the core of the northwest Atlantic biomass and catches are concentrated (FAO 2010b). This would require physical mechanisms to transport early life stages from spawning to nursery grounds, as seen, for example, in Pacific chub mackerel off Japan (Noto and Yasuda 1999), and migration of juveniles/young adults from nursery to spawning grounds as described for the northeast Atlantic mackerel (Uriarte et al. 2001). Evidence of an increasing size/age gradient from the Portugal-Cadiz area to the Moroccan waters provides some support to the above hypothesis. In the northern part of Moroccan waters (north of $26^{\circ} \mathrm{N}$ ), length and age compositions in surveys and landings are similar to those found off Portugal-Cadiz, i.e. a predominance of 19-21 cm, 0to 1-year-old individuals (FAO 2008, 2010). In the southern Moroccan area, most individuals are in the range $23-25 \mathrm{~cm}$ corresponding to 1 and 2 years old, while the 6+ age group is still abundant, suggesting that juveniles/young adults distributed in northern areas migrate south as they become older. However, there seems to be no synchrony in year-class strength between the Moroccan and Portuguese regions: as in Portugal-Cadiz, several good recruitments occurred off Morocco in recent years but recruitment indices point to good 2005 and 2008 year classes (FAO 2010) that do not coincide with the strong year classes identified in Portugal-Cadiz.

Although the above hypothesis cannot be discarded, the possibility that large chub mackerel are more abundant in the Portugal-Cadiz region than suggested by the present data appears to have stronger support. Off Portugal, chub mackerel occurs down to $400 \mathrm{~m}$ depth (Martins and Cardador 1996) and its presence is noticed in the artisanal fishery that operates near those depths; fish size probably increases with depth as in several areas of the species range (Baird 1978, Perrota 1992). Since the acoustic surveys do not go beyond the shelf edge $(\sim 200 \mathrm{~m})$ and purse seiners fish mainly 
within the $100 \mathrm{~m}$ contour (Stratoudakis and Marçalo 2002), large individuals are probably under-sampled in both. This may be aggravated by the fact that larger individuals are expected to swim faster than smaller ones, being therefore less catchable by the relatively small pelagic trawl with a slow trawling speed used in acoustic surveys (Valdemarsen and Misund 1995), as demonstrated for mackerel (Slotte et al. 2007).

Anecdotal information suggests that chub mackerel discards are likely to be high in most fisheries. Discard estimates for bottom trawl fisheries for recent years show that mainly $20-30 \mathrm{~cm}$ individuals (1-3 years) and some larger individuals $(30-40 \mathrm{~cm}, 3-8$ years old) in smaller frequencies are discarded by the fleet targeting crustaceans although the total amount is low, 25-50 t per year (ICES 2012a). On the other hand, the fish bottom trawl fleet makes large discards in some years (3\%-22\% of total landings in 2005-2011) but it is the smallest individuals that dominate the discarded component (18-25 cm, $\sim 1$ year). Thus, some but not a high level of underestimation of large fish in the region is expected from discards. Furthermore, the observed discarding practices suggest that year-class strength is possibly underestimated in this study, namely during 2007-2010 when the volume of discards by fish bottom trawlers was high (mean=3500 t/year, CV about 26\%; ICES 2012a).

The data presented in this study suggest some association between the dynamics of chub mackerel and sardine off the Portugal-Cadiz region. The spatial distribution of the two species shows some degree of complementarity: sardine abundance declines from the northwestern area to south Algarve and increases in the Gulf of Cadiz (Silva et al. 2009), whereas chub mackerel is scarce in the northwest and is more abundant in the southwest and the Gulf of Cadiz. The frequency of occurrence of chub mackerel in the study area correlates significantly but weakly with the abundance of sardine in qualitative terms (ranks) although not in quantitative terms, as demonstrated by the GAM analysis. Although weak, inverse correlations between landings in the past 25 years and even at the historical scale (for landings since 1958: Spearman rho $=-0.42$, $\mathrm{p}<0.002, \mathrm{n}=53$ ) makes the hypothesis of alternation of the two species plausible.

The most striking evidence of interaction between chub mackerel and sardine obtained in the present study is the inverse correlation between their recruitment indices (Fig. 8). Adverse effects of one species on the recruitment of the other species might be caused by competition for food during the larval/juvenile stages, since both species consume mainly zooplankton during that phase (Castro-Hernández and Santana-Ortega 2000, Van der Lingen et al. 2009). Moreover, chub mackerel and sardine may affect each other through predation since both species consume fish eggs and chub mackerel adults feed on juveniles mainly of small pelagic species such as sardine and anchovy (Castro and Hernandéz-García 1995, Garrido et al. 2008).
It is also plausible that environmental conditions which enhance recruitment in one of the species are unfavourable for the recruitment of the other species. Temperature is a possible candidate since it affects growth and survival of early life stages and therefore recruitment success (Rijnsdorp et al. 2009). Moreover, there is some evidence that sardine recruitment is negatively affected by temperature (Santos et al. 2012). The coastal waters off western Portugal have warmed since the 1970s, reflecting a weakening of the upwelling regime (Lemos and Pires 2004, Lemos and Sansó 2006, Relvas et al. 2009). Off Portugal, sardine spawns in autumn-winter when temperature is around the annual minimum $\left(14-15^{\circ} \mathrm{C}\right.$, Coombs et al. 2006), whereas chub mackerel spawns in winter-spring, when temperature has risen $1^{\circ} \mathrm{C}$ to $2^{\circ} \mathrm{C}$ above the minimum. The differences in spawning season suggest that chub mackerel early life stages may be more tolerant to higher temperature than those of sardine, so the warming trend may be favouring chub mackerel recruitment and hindering sardine recruitment. However, other mechanisms are possible: for example, Santos et al. (2007) suggested that the main mechanism responsible for impaired sardine recruitment is the increased frequency and intensity of upwelling events in winter (the spawning season), which promotes the dispersal of eggs and larvae away from suitable shelf areas for their survival.

The northward expansion of chub mackerel off Portugal may be part of a more general northward expansion of "southern" species, possibly linked to warming of the sea. Other than chub mackerel, jack mackerel (Trachurus picturatus, Bowdich, 1825), another pelagic species with southern affinity, has increased off Portugal in recent years (ICES 2008). For chub mackerel the Iberian Peninsula is near the northern limit of its distribution area (the Bay of Biscay; Castro-Hernández and Santana-Ortega 2000). On the other hand, sardine distribution extends to the North Sea, showing large abundance and a major recruitment area in the Bay of Biscay (Silva et al. 2009). Northward shifts in distribution linked to global warming have been documented for numerous pelagic fish populations in the Atlantic, such as mackerel and horse mackerel (Rijnsdorp et al. 2009, ICES 2012b). Moreover, both sardine and anchovy (Engraulis encrasicholus) have expanded their distribution and spawning areas from the English Channel to the entire North Sea (Alheit et al. 2012).

In summary, we have demonstrated fluctuations in the abundance and a northwards shift in distribution of chub mackerel, and a likely inverse relationship with sardine abundance. The fluctuations may be caused by fluctuations in physical conditions, and possible by interaction between species in terms of food competition and predation on early life stages. The northward shift may be part of a more general expansion of species from warmer areas, linked to changing physical conditions that increase the area where the temperature conditions are satisfactory for such species. 


\section{ACKNOWLEDGEMENTS}

The authors wish to thank Yorgos Stratoudakis, whose idea originated this paper. We also acknowledge the work of all IPMA technician teams involved in tasks linked to these species. Thanks are due to the Direcção Geral dos Recursos Naturais Segurança e Serviços Maritimos (DGRM) for the statistics fisheries data made available every year. Data analysed in this work were obtained through the PNAB/EU Data Collection/DCF Programme.

\section{REFERENCES}

Alheit J., Roy C., Kifani S. 2009. Decadal-scale variability in populations. In: Checkley D.M. Jr., Alheit J., Oozeki Y., Roy C. (eds), Climate Change and Small Pelagic Fish. Cambridge University Press, Cambridge, pp. 64-87.

Alheit J., Pohlmann T., Casini M., Greve W., Hinrichs R., Mathis M., O’Driscoll K., Vorberg K., Wagner C., 2012. Climate variability drives anchovies and sardines into the North and Baltic Seas. Progr. Oceanogr. 96: 128-139.

Angelescu V. 1979. Trophic ecology of the mackerel of the Argentine continental shelf. (Scombridae, Scomber japonicus marplatensis) Part I. feeding and growth. Rev. Invest. Desarr. Pesq. 1(1): 6-44.

Baird D. 1978. Catch composition and population structure of the commercially exploited mackerel Scomber japonicus, 19541975. Fish. Bull. S. Afr. 10:50-61.

Castro J.J., Hernández-Garcia V. 1995. Ontogenetic changes in mouth structures, foraging behaviour and habitat use of Scomber japonicus and Illex condetti. In: Bas C., Castro J.J. Lorenzo J.M. (eds), International Symposium on middle- sizzed pelagic fish. Sci. Mar. 59(3-4): 347-355.

Castro Hernández J.J., Santana-Ortega A.T. 2000. Synopsis of biological data on the chub mackerel (Scomber japonicus, 1782). FAO Fish Synop. No. 157. Rome, 77 pp.

Collette B.B. 1999. Mackerels, molecules and morphology. In: Seret B. and Sire J-Y (eds). Proceedings of the 5th Indo-Pacific Fish Conference, Noumea, 1997, pp. 149-164.

Coombs S.H., Smyth T. J., Conway D. V.P., Halliday N.C., Bernal M., Stratoudakis Y., Alvarez P. 2006. Spawning season and temperature relationships for sardine (Sardina pilchardus) in the eastern North Atlantic. J. Mar. Biol. Ass. UK 86: 1245-1252.

Crawford R.J.M. 1983. Aspects of variability of some neritc stocks in the southern Bengela system. In: Sharp G.D., Csirke J. (eds), Proccedings of the expert consultation to examine changes in abundance and species composition of neritic fish resources. San Jose, Costa Rica, 19-29 April 1983. A preparatory meeting for the FAO world conference of fisheries management and development. FAO. Fish. Rep. 291(2): 407-448.

Crone P. R., Hill K.T., McDaniel J.D., Lynn K. 2011. Pacific mackerel (Scomber japonicus) stock assessment for USA management in the 2011-12 fishing year. Pacific Fishery Management Council, 7700 NE Ambassador Place, Suite 101, Portland, Oregon 97220, USA, $100 \mathrm{pp}$.

Cury P., Roy C. 1987. Upwelling et pêche des espèces pélagiques de Côte-d'Ivoire : une approches globale. Oceanol. Acta 10(3): 347-357.

DGPA 2011. Recursos da Pesca. Série ESTATÍSTICA. Vol. 24 A-B. Año 2010

FAO 2010a. Statistics and Information Service of the Fisheries and Aquaculture Department. FAO yearbook. Fishery and Aquaculture Statistics. 2008. Rome, FAO. 2010. 72 pp.

FAO 2010b. Report of the FAO Working Group On The Assessment Of Small Pelagic Fish Off Northwest Africa. Saly, Senegal 6-15 May. Fisheries and Aquaculture Report No. 975, 276 pp.

Foote K., Knudsen H., Vestnes G., MacLennan D., Simmonds E. 1987. Calibration of acoustic instruments for fish density estimation: a practical guide. ICES Coop. Res. Rep. $\mathrm{N}^{\circ} 144$.

Garrido S., Ben-Hamadou R., Oliveira P., Cunha M., Chícharo M., Van der Lingen C. 2008. Diet and feeding intensity of sardine
Sardina pilchardus: correlation with satellite-derived chlorophyll data. Mar. Ecol. Prog. Ser. 354, 245-256.

GFCM 2010. Report of the Scientific Advisory Committee working group on stock assessment of small pelagic species. GFCM: SAC12/2010/Inf.14, $70 \mathrm{pp}$.

ICES 1998. Report of the Planning Group for Acoustic Surveys in ICES Sub-Areas VIII and IX. International Council for the Exploration of the Sea (CM Papers and Reports) CM 1998/G:2, 17 pp.

ICES 2008. Report of the International Bottom Trawl Survey Working Group (IBTSWG). Vigo, Spain, 31 March-4 April 2008. ICES CM 2008/RMC:02.

ICES 2009. Report of the Working Group on Acoustic and Egg Surveys for Sardine and Anchovy in ICES Areas VIII and IX (WGACEGG).16-20 November 2009, Lisbon, Portugal. ICES CM 2009/LCR:20, $181 \mathrm{pp}$

ICES 2010. Report of the Working Group on Acoustic and Egg Surveys for Sardine and Anchovy in ICES Areas VIII and IX (WGACEGG), 22-26 November 2010. ICES CM 2010/ SSGESST:24, $210 \mathrm{pp}$.

ICES 2011a. Report of the Working Group on Widely Distributed Stocks (WGWIDE), 23-29 August 2011. ICES headquarters, Copenhagen, Denmark, ICES CM 2011/ACOM:15, 642 pp.

ICES 2011b. Report of the Working Group on Anchovy and Sardine (WGANSA), 24-28 June 2011, Vigo, Spain. ICES CM 2011/ ACOM:16, $462 \mathrm{pp}$.

ICES 2011c. Report of the Working Group on Acoustic and Egg Surveys for Sardine and Anchovy in ICES Areas VIII and IX (WGACEGG), 21-25 November 2011, Barcelona, Spain. ICES CM 2011/SSGESST:20, 157 pp.

ICES 2012a. Report of the Working Group on Widely Distributed Stocks (WGWIDE), 21-27 August 2012, Lowestoft, United Kingdom. ICES CM 2012/ACOM:15, 931 pp.

ICES 2012b. Report of the Working Group on Small Pelagic Fishes, their Ecosystems and Climate Impact (WGSPEC). 27 February-2 March 2012, Fuengirola, Spain. ICES CM 2012/ SSGEF:10 REF. SCICOM

INE 2011. Anuário Estatístico de Portugal. Year book of Portugal. Instituto Nacional de Estatística, I.P.

Infante C., Blanco E., Zuasti E., Crespo A., Manchado M. 2007. Phylogenetic differentiation between Atlantic Scomber colias and Pacific Scomber japonicus based on nuclear DNA sequences. Genetica 130: 1-8.

Jardim E., Trujillo V., Sampedro P. 2004. Uncertainties in sampling procedures for age composition of hake and sardine in Iberian Atlantic Waters. Sci. Mar. 68: 561-569.

Lemos R.T., Pires H.O. 2004. The upwelling regime off the west Portuguese coast, 1941-2000. Int. J. Climatol. 24: 511-524.

Lemos R.T., Sansó B. 2006. Spatio-temporal variability of ocean temperature in the Portugal Current System. J. Geophys. Res. B 111: C04010, doi: 10.1029/2005JC003051.

Martins, M.M. 1996. New biological data on growth and maturity of Spanish Mackerel (Scomber japonicus) off the Portuguese coast (ICES Division IX a). ICES C. M. $1996 \mathrm{H}: 23,17 \mathrm{pp}$.

Martins M.M., Cardador F. 1996. Abundance and distribution pattern of Spanish Mackerel (Scomber japonicus) and Mackerel (Scomber scombrus) in the Portuguese continental waters (ICES DIV. IX a). ICES C. M. $1996 \mathrm{H}: 24,21 \mathrm{pp}$.

Martins M.M. 2007. Growth variability in Atlantic mackerel (Scomber scombrus) and Spanish mackerel (Scomber japonicus) off Portugal. - ICES J. Mar. Sci. 64: 1785-1790.

Noto M., Yasuda I. 1999. Population decline of Japanese sardine with relation to sea-surface temperature in Kuroshio Extension. Can. J. Fish. Aqua. Sci. 56: 973-983.

Parrish R.H., MacCall A.D. 1978. Climatic variation and exploitation in the Pacific mackerel fishery. Calif. Dep. Fish Game, Fish Bull., 167, 110 pp.

Pecquerie L., Drapeau L, Fréon P., Coetzee J.C., Leslie R.W., Griffiths, M.H. 2004. Distribution patterns of key fish species of the southern Benguela ecosystem: an approach combining fishery-dependent and fishery-independent data. Afr. J. Mar. Sci. 26: 115-139.

Perrota R.G. 1992. Growth of mackerel (Scomber japonicus Houttuyn, 1782) from Buenos Aires - north Patagonian region (Argentine Sea). Sci. Mar. 56: 7-16.

Relvas P., Luís J., Santos A.M.P. 2009. Importance of the mesoscale in the decadal changes observed in the northern Canary upwell- 
ing system. Geophys. Res. Lett. 36: L2260.

Rijnsdorp A. D., Peck M. A., Engelhard G. H., Mollmann C., Pinnegar J. K. 2009. Resolving the effect of climate change on fish populations. ICES J. Mar. Sci. 66: 1570-1583.

Santos A.M.P., Chícharo A, dos Santos A, Moita T, Oliveira P.B, Peliz A, Ré P. 2007. Physical-biological interactions in the life history of small pelagic fish in the western Iberia upwelling ecosystem. Prog. Oceanogr. 74: 192-209.

Santos M.B., González-Quirós R., Riveiro I., Cabanas J.M., Porteiro C., Pierce G.J., 2012. Cycles, trends and residual variation in the Iberian sardine (Sardina pilchardus) recruitment series and their relationship with the environment. ICES J. Mar. Sci. 69: 739-750.

Scoles D.R., Collette B.B., Graves J.E. 1998. Global phylogeography of mackerels of the genus Scomber. Fish. Bull. 96: 823-842.

Silva A., Skagen D.W., Uriarte A., Massé J., Santos M.B., Marques V., Carrera P., Beillois P., Pestana G., Porteiro C., Stratoudakis Y. 2009. Geographic variability of sardine dynamics in the Iberian Biscay region. ICES J. Mar. Sci. 66: 495-508.

Slotte A., Skagen D., Iversen S.A. 2007. Size of mackerel in research vessel trawls and commercial purse-seine catches: implications for acoustic estimation of biomass. ICES J. Mar. Sci. 64: 989-994

Sousa P., Azevedo M., Gomes M. C. 2005. Demersal assemblages off Portugal: Mapping, seasonal, and temporal patterns. Fish Res. 75: 120-137.

Stratoudakis Y., Marçalo A. 2002. Sardine slipping during purse-seining off northern Portugal. ICES J. Mar. Sci. 59(6): 1256-1262.

Suda M., Watanabe C., Akamine T. 2008. Two-species population dynamics model for Japanese sardine Sardinops melanostictus and chub mackerel Scomber japonicus off the Pacific coast of Japan. Fish Res. 94: 18-25.

Uriarte A., Alvarez P., Iversen S., Molloy, J.,Villamor, B., Martins, M.M., Myklevoll, S. 2001. Spatial pattern of migration and recruitment of North East Atlantic Mackerel. ICES C.M. 2001 /O: $17,40 \mathrm{pp}$

Valdemarsen J.W., Misund O.A. 1995. Trawl designs and techniques used by Norwegian research vessels to sample fish in the pelagic zone. In: Hylen A. (ed.), Proceedings of the sixth PRlW-PEWO symposium, Bergen, 14-17 June 1994, Institute of Marine Research, Bergen, Norway, pp. 135-144.

Van der Lingen C.D., Arnaud B., Bode A., Brodeur R., Cubillos L.A., Espinoza P., Friedland K., Garrido S., Irigoien X., Miller T., Möllmann C., Rodriguez-Sanchez R., Tanaka H., Temming A. 2009. Trophic dynamics. In: Checkley D.M. Jr., Alheit, J., Oozeki, Y. Roy, C (eds), Climate change and small pelagic fish. Cambridge University press, pp. 112-157.

Villamor B, Abaunza P., Fariña A.C. 2004. Growth variability of mackerel (Scomber scombrus) off north and northwest Spain and a comparative review of the growth patterns in the northeast Atlantic. Fish. Res. 69: 107-121.

Watanabe Y. 2009. Recruitment Variability of Small Pelagic Fish Populations in the Kuroshio-Oyashio Transition Region of the Western North Pacific. J. Northw. Atl. Fish. Sci. 41: 197-204.

Weill A., Scalabrin C., Diner N. 1993. MOVIESB: An acoustic detection description software. Application to shoal species classification. Aquat. Living Resour. 6: 255-267.

Wood S.N. 2006. Generalized additive models. Chapman \& Hall/ CRC, 384 pp.

Yatsu A.,Watanabe T., Ishida M., Sugisaki H., Jacobson L.D. 2005. Environmental effects on recruitment and productivity of Japanese sardine Sardinops melanostictus and chub mackerel Scomber japonicus with recommendations for management. Fish Oceanogr. 14: 263-278.

Zardoya R., Castilho R., Grande L., Favre-Krey L., Caetano S., Marcato S., Krey G., Patarnello T. 2004. Differential population structuring of two closely related fish species, the mackerel (Scomber scombrus) and the chub mackerel (Scomber japonicus), in the Mediterranean Sea. Mol. Ecol. 13: 1785-1798.

Zwolinski J., Fernandes G.P., Marques V., Stratoudakis Y. 2009. Estimating fish abundance from acoustic surveys: calculating variance due to acoustic backscatter and length distribution error. Can. J. Fish. Aquat. Sci. 66: 2081-2095.

Scient. ed.: S. Somarakis.

Received April, 2, 2013. Accepted October 4, 2013.

Published online November 7, 2013. 